\title{
REPASSIVATION OF THE DAMAGE GENERATED BY CAVITATION ON \\ UNS N08031 IN A LiBr SOLUTION BY MEANS OF ELECTROCHEMICAL TECHNIQUES AND CONFOCAL LASER SCANNING MICROSCOPY
}

\section{Fernández-Domene, R.M., Blasco-Tamarit, E., García-García, D.M., García-}

\author{
Antón, J. * \\ Ingeniería Electroquímica y Corrosión (IEC). Departamento de Ingeniería Química y \\ Nuclear. ETSI Industriales. Universidad Politécnica de Valencia. P.O. Box 22012, E- \\ 46071 Valencia. Spain.
}

Tel.34-96-387 76 30, Fax.34-96-387 76 39, e-mail.jgarciaa@iqn.upv.es

The objective of this work is to study the influence of cavitation on the corrosion behaviour of Alloy 31, a highly-alloyed austenitic stainless steel (UNS N08031), in a $\mathrm{LiBr}$ heavy brine solution $(992 \mathrm{~g} / \mathrm{l})$ at $25^{\circ} \mathrm{C}$. The presence of cavitation shifted the OCP

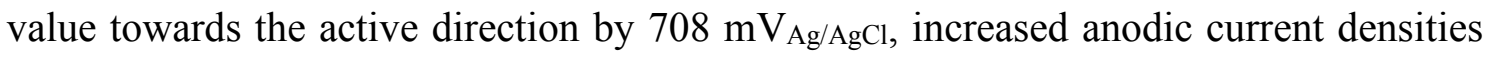
and passivation current density, $i_{p}$, and reduced the pitting potential, $E_{p}$.

Repassivation behaviour of Alloy 31 has been investigated by using potentiostatic tests at different potentials. The current density transient obtained after interrupting cavitation was used to obtain the repassivation index, $n$, provided by the slope of the $\log$ $i(t)$ vs. $\log t$ representation. The value of $n$ decreased as the applied potential was increased, reaching values near zero for potentials close to the pitting potential. The damage generated during the potentiostatic tests has been quantified by means of Confocal Laser Scanning Microscopy. 
Keywords: A. Stainless steel; B. Polarization, potentiostatic; C. Repassivation, pitting corrosion

\section{INTRODUCTION}

Most refrigeration systems which use natural gas or water steam as energy sources employ highly concentrated aqueous solutions of lithium bromide ( $\mathrm{LiBr})$ as absorbent solutions [1,2]. The absorption units reduce the use of chlorofluorocarbons (CFCs). These refrigerants are banned (Montreal Protocol, 1987) and their substitutes are submitted to severe legislation (Kyoto Protocol, 1997), since they are partially responsible for the depletion of the ozone layer. Thus, refrigeration absorption technology constitutes a suitable alternative to compression systems.

Although $\mathrm{LiBr}$ solutions possess favourable thermophysical properties [1-3], they can cause serious corrosion problems on the metallic components in absorption plants. There are several references to corrosion caused by $\mathrm{LiBr}$ solutions on engineering materials, such as copper and copper alloys [4-6], stainless steels [2,3,7,8], carbon steels [3] and titanium $[2,3,9]$.

Apart from the corrosive nature of highly concentrated $\mathrm{LiBr}$ solutions, the cavitation phenomenon can take place in numerous points of the absorption machines, such as pumps, valves, elbows, narrowings, etc. Cavitation is caused by continuous collapse of many bubbles generated due to local pressure changes during high-velocity flow [10]. The combined action of corrosion and cavitation can make the material experience more 
damage than if each phenomenon acted separately, that is, there is a synergistic effect [10-13]. However, in spite of the importance of hydrodynamic factors on the corrosion behaviour of engineering materials, there is little information published about the cavitation-corrosion phenomena [11,13,14-19].

The development of corrosion resistant metallic materials has become one of the key issues in new absorption systems, where higher concentrations of $\mathrm{LiBr}$ are reached. High-alloyed austenitic stainless steels, such as Alloy 31, present greater amounts of alloying elements, namely chromium (Cr), molybdenum (Mo) and nickel (Ni), as compared with the established $18 \% \mathrm{Cr}, 10 \% \mathrm{Ni}$ baseline steels. The high chromium content of these alloys results in great corrosion resistance due to the protective oxide layer formed on their surface [8,20,21]. A high nickel content in the alloy increases pitting corrosion resistance [8,22,23], mainly by increasing pitting potential. Molybdenum also improves pitting corrosion resistance in these alloys [8,24,25], but its main effect is to facilitate repassivation after passive film breakdown [26].

Passivity of stainless steels is due to a thin surface film whose composition can be considered, for most purposes, as $2 \mathrm{~nm}$ of microcrystalline chromium oxide $\left(\mathrm{Cr}_{2} \mathrm{O}_{3}\right)$ $[27,28]$. The passive film stability is of paramount importance to protect the metal from corrosion attacks. Thus, if this film is broken somehow, localized attacks may occur. Therefore, it is necessary to know if the passive film will regenerate after being damaged, and the rate of this repassivation.

In order to simulate film breakdown and quantify the repassivation kinetics, some methods have been proposed, such as the abrading electrode technique [29-32] or the 
scratching electrode method [33-38]. The present work develops a method in which passive film breakdown is produced by cavitation to study the repassivation kinetics of metals. The damage generated on the Alloy 31 surface has also been quantified by means of image analysis and Confocal Laser Scanning Microscopy (CLSM).

\section{EXPERIMENTAL PROCEDURE}

\section{Materials and specimen preparation}

The material tested was the highly-alloyed austenitic stainless steel Alloy 31 (UNS N08031: $26.75 \% \mathrm{Cr}, 31.85 \% \mathrm{Ni}, 1.50 \% \mathrm{Mn}, 0.10 \% \mathrm{Si}, 6.60 \% \mathrm{Mo}, 1.21 \% \mathrm{Cu}, 31.43 \%$ Fe, $0.002 \% \mathrm{~S}, 0.017 \% \mathrm{P}, 0.005 \% \mathrm{C}, 0.193 \% \mathrm{~N})$, provided by ThyssenKrupp VDM. Alloy 31 electrodes were cylindrically shaped (8- $\mathrm{mm}$ diameter and $55 \mathrm{~mm}$ long) and covered with a polytetrafluoroethylene (PTFE) coating. The exposed area to the solution was $0.5 \mathrm{~cm}^{2}$. All specimens were wet abraded from $500 \mathrm{SiC}$ (silicon carbide) grit to $4000 \mathrm{SiC}$ grit, and finally rinsed with distilled water.

The potentiodynamic and potentiostatic experiments carried out in this work were performed in a LiBr heavy brine solution (992 g/l), prepared from very pure $\mathrm{LiBr}(98$ wt.\%) from PANREAC.

\section{Potentiodynamic tests}

Under static condition (without cavitation) cyclic potentiodynamic polarization curves of Alloy 31 were determined using a Solartron 1287 potentiostat, at $25^{\circ} \mathrm{C}$. In all cases, tests were repeated at least three times. The experimental arrangement consists of two 
parts: a horizontal electrochemical cell $[39,40]$ with the data acquisition equipment and an image acquisition unit formed by a trinocular microscope-stereoscope (NIKON SMZ-U) zoom 1:10 and a colour video camera (SONY SSC-C370P). The image acquisition unit allows observing the electrode surface in real-time during potentiodynamic polarization and to relate the events that take place on the electrode surface to the polarization curve.

The working electrode potential was measured vs. a silver-silver chloride $(\mathrm{Ag}-\mathrm{AgCl})$ reference electrode with $3 \mathrm{M}$ potassium chloride $(\mathrm{KCl})$ solution. The auxiliary electrode was a platinum (Pt) wire. Nitrogen was bubbled for 10 minutes before and during the test in order to remove the oxygen present in the system. Before each polarization measurement, the Open Circuit Potential (OCP) was measured for 1 hour in the test solution. The average value of the potentials recorded during the last $300 \mathrm{~s}$ was the value of the OCP (ASTM G-5 [41]). After the OCP test, the specimen potential was reduced in four steps to $-1000 \mathrm{mV}_{\mathrm{Ag} / \mathrm{AgCl}}$ for $60 \mathrm{~s}$, with the aim of creating reproducible initial conditions. Then, the electrode potential was scanned from $-1000 \mathrm{mV} \mathrm{Ag} / \mathrm{AgCl}$ at $1 \mathrm{mV} / \mathrm{s}$. When the current density reached $10 \mathrm{~mA} / \mathrm{cm}^{2}$, the potential scan was reversed in order to evaluate the repassivation tendency. The temperature of the system $\left(25^{\circ} \mathrm{C}\right)$ was not changed during the experiments.

From the $E$ - $\log i$ plot, the corrosion potential $\left(E_{\text {corr }}\right)$ and corrosion current density $\left(i_{c o r r}\right)$ were obtained using the Tafel slopes; in addition, the pitting potential $\left(E_{p}\right)$ was defined as the potential at which the current density reaches $100 \mu \mathrm{A} / \mathrm{cm}^{2}$. The current density before pitting is almost constant and is defined as the passive current density $\left(i_{p}\right)$. The repassivation potential values $\left(E_{r p}\right)$ were taken at the crossing between the backward 
scan and the forward scan. The difference between $E_{p}$ and $E_{r p}$ shows the susceptibility of a metallic material to localized attack in a given media [20,42]. Repassivation current density $\left(i_{r p}\right)$ was also obtained.

Cavitation tests were performed using an ultrasound device with a $550 \mathrm{~W}$ output power, a $20 \mathrm{kHz}$ output frequency and a peak-to-peak amplitude $(\mathrm{pp} A)$ of $120 \mu \mathrm{m}$. The horn tip is $12.7 \mathrm{~mm}$ in diameter. The experimental arrangement used is represented in Figure 1. The arrangement consists of two units: the ultrasonic-induced cavitation facility and the electrochemical cell. The working electrode is placed co-axially with the horn and is held stationary at a distance of $10 \mathrm{~mm}$ from the horn tip.

The oxygen was removed from $\mathrm{LiBr}$ solutions by bubbling nitrogen for $10 \mathrm{~min}$ prior to the tests. Nitrogen was also bubbled during the whole test. Before each anodic polarization, the Open Circuit Potential test without cavitation was carried out for 55 min. When the ultrasonic device was connected the value of the OCP was measured for $5 \mathrm{~min}$, and after that the working electrode was shifted to $-1000 \mathrm{mV}_{\mathrm{Ag} / \mathrm{AgCl}}$. The potentiodynamic polarization was carried out with a scan of rate $1 \mathrm{mV} / \mathrm{s}$ from -1000 $\mathrm{mV}_{\mathrm{Ag} / \mathrm{AgCl}}$ towards the anodic direction. A silver-silver chloride reference electrode with $3 \mathrm{M}$ potassium chloride solution and a platinum mesh auxiliary electrode were used in these experiments. The temperature was maintained at $25^{\circ} \mathrm{C}$. As under static conditions, tests were repeated at least three times. Under cavitation conditions the following parameters were obtained: $E_{c o r r}, i_{c o r r}, i_{p}, E_{p}, i_{r p}$ and $E_{r p}$. 
Finally, the samples subjected to cavitation were rinsed and examined with the Confocal Laser Scanning Microscope Olympus LEXT OLS3100, which uses the LEXT OLS 6.0.3 software. The CSLM uses a Laser Diode with a wavelength of $408 \mathrm{~nm}$, an outstanding horizontal resolution of $0.22 \mu \mathrm{m}$, vertical resolution of $0.01 \mu \mathrm{m}$ (z-axis), and a magnification range from $120 \mathrm{x}$ to $14400 \mathrm{x}$. Under static conditions, the damage was not deep and therefore there was no point in using the CSLM.

\section{Potentiostatic repassivation tests}

For repassivation tests, the device shown in Figure 1 was also used. However, there were two important procedure differences between potentiodynamic tests under cavitation conditions and repassivation tests. First, the horn tip was not the same; in this case, the tip had a diameter of $1.6 \mathrm{~mm}$, so it will cause more localized damage. Secondly, the distance between the working electrode and the horn tip was $1 \mathrm{~mm}$ when cavitation was applied on the electrode surface, with the purpose of ensuring more concentrated damage.

The potentiodynamic cyclic curves of Alloy 31 under static conditions were used to set the four values of the imposed potentials. To ensure a correct passivity of the Alloy 31 surface before starting the repassivation test, a number of steps were followed. Once the selection of the applied potentials was established by means of the potentiodynamic curves, the electrode was immersed in the test solution for $1 \mathrm{~h}$ (Open Circuit Potential test). After that, the potential was reduced from the OCP value to $-1000 \mathrm{mV}_{\mathrm{Ag} / \mathrm{AgCl}}$ in four potentiostatic steps of 15 seconds each. The potential was swept at $1 \mathrm{mV} / \mathrm{s}$ from $1000 \mathrm{mV} \mathrm{Ag} / \mathrm{AgCl}$ to the chosen potential. When the selected potential was reached, it was held for 1 minute under static conditions. Then, cavitation was switched on for another 
minute. After that, the potentiostatic test continued for 1 extra hour at the selected potential, with cavitation disconnected.

During the whole potentiostatic test, the resulting change in current density was acquired at the constant applied potential. The transient obtained just after disconnecting cavitation was then used to obtain the repassivation index, $n$, and the pit growth kinetics index, $b$, from the downward and ascending slope of the logarithmic representation log $i(\mathrm{t})$ vs. $\log t$, respectively.

Once the test finished, the electrodes were rinsed with distilled water to quantify the generated damage by using Confocal Laser Scanning Microscopy (CLSM). The tests were repeated three times.

Finally, a cavitation-erosion test using distilled water was carried out following the same procedure, but without applying any potential. The damage generated was also quantified using the Confocal Laser Scanning Microscope, in order to compare the results in water and in the $\mathrm{LiBr}$ solution.

\section{RESULTS}

Potentiodynamic tests

OCP (Open Circuit Potential) 
The OCP values of Alloy 31 in $992 \mathrm{~g} / 1 \mathrm{LiBr}$ solutions under static and cavitation conditions are shown in Table 1. In the absence of cavitation, the OCP measurement was quite stable, though it shifted slowly to the noble direction, which indicates the good properties of the passive film $[8,43]$. The OCP value of the specimen immersed in quiescent $\mathrm{LiBr}$ solution was $-248 \mathrm{mV}$ Ag/AgCl . The presence of cavitation shifted the OCP value towards the active direction by $708 \mathrm{mV}_{\mathrm{Ag} / \mathrm{AgCl}}$. This displacement observed in the OCP when cavitation was present is similar to other results obtained by other authors $[11,13,14,16,17,44,45]$. Figure 2 shows the images of the electrode surface before and after the OCP test with cavitation. It can be observed that the surface did not suffer any visible damage.

Potentiodynamic polarization cyclic curves

Figure 3 illustrates the potentiodynamic polarization cyclic curves for Alloy 31 in 992 $\mathrm{g} / 1 \mathrm{LiBr}$ solution under static $(p p A=0 \mu \mathrm{m})$ and cavitation $(p p A=120 \mu \mathrm{m})$ conditions. Table 2 lists the characteristic parameters values for both curves.

The cathodic current densities were higher under cavitation conditions than under static conditions. Besides, the corrosion potential, $E_{c o r r}$, shifted towards nobler values. The value of $i_{\text {corr }}$ also rose with cavitation.

Besides, both curves show a wide passive zone, where current density is almost constant. Regarding the passive current density, its value was about five times higher under cavitation conditions than under static ones. The extent of this passive zone was 
also affected by the presence of cavitation, due to the displacement of the pitting potential $\left(E_{p}\right)$ from $0.53 \mathrm{~V} \mathrm{Ag} / \mathrm{AgCl}$ (without cavitation) to $0.32 \mathrm{~V}_{\mathrm{Ag} / \mathrm{AgCl}}$ (with cavitation). The passive region under static conditions has a range of $1200 \mathrm{mV}$, and it falls to 870 $\mathrm{mV}$ with cavitation.

The polarization curves also show that, once the pitting potential was reached, the current density increased sharply, which indicates the passive film breakdown. This rise in current density was also modified by cavitation. Current density augmented more sharply under static conditions than under cavitation ones. The repassivation current density, $i_{r p}$, was lower in the presence of cavitation.

When Alloy 31 was exposed to cavitation the extent of the hysteresis loop (unstable passivity region) was reduced if compared with that under static conditions $(0.59$ $\mathrm{V}_{\mathrm{Ag} / \mathrm{AgCl}}$ without cavitation and $0.35 \mathrm{~V}_{\mathrm{Ag} / \mathrm{AgCl}}$ with cavitation), though the repassivation potential, $E_{r p}$, hardly changed. The stable passivity zone $\left(E_{r p}-E_{c o r r}\right)$ was smaller under cavitation conditions than under static conditions, but the difference was only $39 \mathrm{mV}$.

\section{Morphological examinations and damage quantification}

Figures 4 and 5 show the appearance of the electrodes surface after the potentiodynamic tests, under static and cavitation conditions respectively, in the $992 \mathrm{~g} / \mathrm{l}$ LiBr solution. 
Under static conditions, the morphology of corrosion seems to be uniform (Figure 4a). However, corrosion began at localized sites of the surface and continued through the paths formed by the corrosion products generated from the sites. Figure $\mathbf{4 b}$ is a magnified image of the selected zone on Figure 4a, and shows many round pits distributed inside the Alloy 31 grains. Hence, Alloy 31 presents localized corrosion under static conditions.

Under cavitation conditions (Figure 5), the attack morphology is rather different than that under static ones, showing well-defined pits throughout the metal surface. The pits have approximately circular morphology and similar size.

The damaged area of Alloy 31 after the cyclic potentiodynamic test in the $992 \mathrm{~g} / 1 \mathrm{LiBr}$ solution was obtained from the binarized images of the electrode surface, using the image analysis software Visilog 6.3. The percentage of the corroded area with regard to the total electrode area was $69.08 \%$ (static conditions) and $0.63 \%$ (cavitation conditions). However, the attack is deeper and more localized under cavitation conditions.

Regarding the pits produced on the Alloy 31 surface under cavitation conditions, the following mean values were obtained using the Confocal Laser Scanning Microscope: the mean volume was $1.89 \cdot 10^{5} \mu \mathrm{m}^{3}$, the mean base area was $1.23 \cdot 10^{4} \mu \mathrm{m}^{2}$ and the mean surface area was $8.16 \cdot 10^{4} \mu \mathrm{m}^{2}$.

By way of illustration, Figure 6a shows the 2D image of a pit formed on the Alloy 31 surface in the $992 \mathrm{~g} / \mathrm{l} \mathrm{LiBr}$ solution under cavitation conditions, and Figure $6 \mathrm{~b}$ 
illustrates a 3D image of the same pit, taken with the Confocal Laser Scanning Microscope.

As an example, in order to visualize the selected pit morphology and to quantify its depth, two profiles (longitudinal and transverse) have been drawn (Figure 6c). From these profiles, it can be observed that the pit has the shape of an inverted cone.

\section{Repassivation behaviour}

Linear curves current density (i) vs. time ( $t$ )

From the polarization curve for Alloy 31 in $992 \mathrm{~g} / 1 \mathrm{LiBr}$ under static conditions, four potentials were selected. The four chosen potentials (-400 $\mathrm{mV}_{\mathrm{Ag} / \mathrm{AgCl}},-200 \mathrm{mV} \mathrm{Ag}_{\mathrm{AgCl}}, 0$ $\mathrm{mV}_{\mathrm{Ag} / \mathrm{AgCl}}$ and $\left.200 \mathrm{mV} \mathrm{Ag}_{\mathrm{AgCl}}\right)$ are shown in Figure 3.

Values of $-400 \mathrm{mV} \mathrm{Ag} / \mathrm{AgCl}$ and $-200 \mathrm{mV} \mathrm{Ag} / \mathrm{AgCl}$ were picked from the region between $E_{\text {corr }}$ and $E_{r p}$, which is known as perfect passivity region. In this region, stable pits cannot be generated and metal shows immunity against pitting attack. Moreover, at potentials above $E_{r p}$ any pre-existent pit is immediately repassivated $[8,20,42,46]$. However, the occurrence of metastable pitting corrosion is possible in this region [29,47-49].

Values of $0 \mathrm{mV}_{\mathrm{Ag} / \mathrm{AgCl}}$ and $200 \mathrm{mV} \mathrm{Ag} / \mathrm{AgCl}$ are located between $E_{r p}$ and $E_{p}$, which is the unstable passivity region. Intermediate potential values do not permit new pits to be formed, but those pits which have already been formed will be able to grow $[8,46,48]$. 
Figure 7a shows the linear current density-time curves at the four applied potentials ($400 \mathrm{mV}$ Ag/AgCl, $-200 \mathrm{mV}_{\mathrm{Ag} / \mathrm{AgCl},} 0 \mathrm{mV} \mathrm{Ag}_{\mathrm{AgCl}}$ and $\left.200 \mathrm{mV} \mathrm{Ag} / \mathrm{AgCl}\right)$. In this figure it can be observed that 60 seconds after the beginning of the test, cavitation was connected (cavitation $\mathrm{ON}$ ), obtaining a current density increment during this period. Although the whole potentiostatic test duration was 1 hour, Figure 7a displays only the first 300 seconds, so that the interval of time when cavitation was connected can be clearly observed.

In Figure 7b, it can be observed that there are differences between potentials of the perfect passivity region $\left(-400 \mathrm{mV} \mathrm{Ag}_{\mathrm{AgCl}}\right.$ and $\left.-200 \mathrm{mV}_{\mathrm{Ag} / \mathrm{AgCl}}\right)$ and the potentials of the unstable passivity region $\left(0 \mathrm{mV}_{\mathrm{Ag} / \mathrm{AgCl}}\right.$ and $\left.200 \mathrm{mV}_{\mathrm{Ag} / \mathrm{AgCl}}\right)$. At the latter potentials, larger values of current density were reached.

For all the tests, upon connecting the cavitation device, a sharp increase in current density was produced. For $-400 \mathrm{mV} \mathrm{Ag}_{\mathrm{AgCl}}$ and $-200 \mathrm{mV} \mathrm{Ag} / \mathrm{AgCl}_{\text {potentiostatic }}$ tests, the increment in current density is not too large (about $5-10 \mu \mathrm{A} / \mathrm{cm}^{2}$ ); for $0 \mathrm{mV}_{\mathrm{Ag} / \mathrm{AgCl}}$, this increment is similar, but continuous. Besides, at $0 \mathrm{mV}_{\mathrm{Ag} / \mathrm{AgCl}}$, big transients with amplitudes higher than $10 \mu \mathrm{A} / \mathrm{cm}^{2}$ are observed between 120 and 180 seconds; these transients could be related to metastable pitting events on the electrode surface $[29,47-$ 49]. For $200 \mathrm{mV}_{\mathrm{Ag} / \mathrm{AgCl}}$ test, this rise certainly is significant (about $30 \mu \mathrm{A} / \mathrm{cm}^{2}$ ).

Figure 7c shows the changes in current density after turning off cavitation (until 300 seconds). For the perfect passivity region potentials $\left(-400 \mathrm{mV}_{\mathrm{Ag} / \mathrm{AgCl}}\right.$ and -200 $\mathrm{mV}_{\mathrm{Ag} / \mathrm{AgCl}}$ ), the current density plummeted, taking lower values than before cavitation, when the metal surface was completely passivated (Figure 7c). 
For the $0 \mathrm{mV}_{\mathrm{Ag} / \mathrm{AgCl}}$ test, the descent of current density signal after cavitation was much more gradual, maintaining the same value as before cavitation for approximately 300 seconds. Nevertheless, from then on, the value was not stable any more, rising irregularly until almost $6 \mu \mathrm{A} / \mathrm{cm}^{2}$. This value was higher than during cavitation. Figure 8 shows the whole potentiostatic curve at $0 \mathrm{mV}_{\mathrm{Ag} / \mathrm{AgCl}}$, in order to observe this growth of current density with time.

At $200 \mathrm{mV}$ Ag/AgCl, current density did not decrease after turning cavitation off, but the signal kept increasing until reaching the value of $40 \mu \mathrm{A} / \mathrm{cm}^{2}$ at the end of the test, so no kind of repassivation was achieved.

Logarithmic curves $\log i(t)$ vs. $\log t$

To describe the repassivation kinetics, $\log i(t)$ vs. $\log (t)$ were plotted based on the following empirical equation on repassivation [29-31,33,36,51]:

$$
i(t)=A \cdot t^{-n}
$$

where $i(t)$ is the anodic current density consumed in the rebuilding of the passive film at time $t$ after switching cavitation off, $A$ is a constant and $n$ is the repassivation index, which is a constant value for a given environment-metal system. This parameter can be obtained from the linear region slope, in logarithmic scale:

$$
\log i(t)=\log A-n \cdot \log t
$$


The parameter $n$ can be considered as an indirect measure of the rate of formation of the passive film upon the fresh metal surface, and depends, among others, on the applied anodic potential [30,31]. In general, the higher the value of $n$, the faster the repassivation process.

Figure 9 illustrates the current density variation with time in logarithmic scale, as well as the fitting of the linear zone, according to eq. 2 . These data were obtained just after disconnecting cavitation at the four selected potentials for Alloy 31. In this figure, according to the different slopes of each curve, they were divided into three different sections or stages, as other authors did for austenitic stainless steels [29] and for aluminium and its alloys [31,32].

For the $200 \mathrm{mV} \mathrm{Ag} / \mathrm{AgCl}$ test, it is observed that there is no linear zone with a downward slope, but in the third stage the value of current density ascended. This increase in current density can be described in terms of kinetics of pit growth [29,31,32] which is given by:

$$
i(t)=B \cdot t^{b}
$$

where $B$ is a constant and $b$ represents the pit growth kinetics index, obtained from the ascending slope of the linear zone in the third stage.

Table 3 shows the repassivation index values, $n$, obtained at $-400 \mathrm{mV}_{\mathrm{Ag} / \mathrm{AgCl}},-200$ $\mathrm{mV}_{\mathrm{Ag} / \mathrm{AgCl}}$ and $0 \mathrm{mV} \mathrm{Ag} / \mathrm{AgCl}$, and the value of the parameter $b$ for $200 \mathrm{mV}_{\mathrm{Ag} / \mathrm{AgCl}}$. It can be observed that $n$ varies with applied potential, decreasing with increasing applied potentials. 


\section{Damage quantification}

The previous results show that the recorded current densities for Alloy 31 rise with increasing applied potentials. This means that upon increasing the potential, the metal oxidation rate becomes higher and the passive film properties get worse. Furthermore, at elevated potentials, the repassivation rate diminishes or even a real repassivation ceases to exist. Consequently, the passive film is not only losing protection capacity, but also it cannot regenerate enough to keep protecting the metal after suffering a physical damage.

In order to verify these results, the damage created by cavitation-corrosion on the Alloy 31 surface was quantified at the four chosen potentials. Figure 10 shows the different damages generated by cavitation-corrosion on the Alloy 31 surface in the $992 \mathrm{~g} / 1 \mathrm{LiBr}$ solution, at the four selected potentials. The red areas in Figure 10, which were obtained from binarized images of the microphotographs and superimposed to the images of the damaged surfaces, show the area of maximum depth of the damage. At first sight, it can be noticed that the more active the applied potential, the larger the magnitude of the generated damage. Table 4 gathers the mean parameters of the produced damages.

It can be clearly observed that as the applied potential increased, the cavitationcorrosion damage upon the Alloy 31 surface becomes higher (Figure 10). Moreover, there are clear differences between the damage produced at perfect passivity region potentials $(-400 \mathrm{mV}$ and $-200 \mathrm{mV})$ and at unstable passivity region potentials $(0 \mathrm{mV}$ and $200 \mathrm{mV}$ ). At $0 \mathrm{mV}_{\mathrm{Ag} / \mathrm{AgCl}}$ and $200 \mathrm{mV}_{\mathrm{Ag} / \mathrm{AgCl}}$, the volume, the lateral surface area 
and the maximum depth of the damage are higher than at $-400 \mathrm{mV}_{\mathrm{Ag} / \mathrm{AgCl}}$ and -200 $\mathrm{mV}_{\mathrm{Ag} / \mathrm{AgCl}}$ (Table 4).

In Figure 11, it can be observed that there is a linear relationship between the damaged area (due to cavitation-corrosion) and the applied potential.

\section{DISCUSSION}

\section{Effect of cavitation on the corrosion behaviour of Alloy 31}

In the present work, the OCP value under cavitation conditions was rather lower than that obtained under static conditions (Table 1). Two effects are referenced to explain the OCP shift due to cavitation $[13,14,44,52]$. On the one hand, the mechanical action of cavitation can destroy or diminish the thickness of the passive film, resulting in the generation of fresh metallic surface. On the other hand, the increase of stirring due to cavitation can produce a reduction in the diffusion layer thickness without damaging the passive film, favouring the oxidant species transport to the electrode surface $[13,14,44,52-54]$. The former case will shift the OCP value in the direction of more active potentials because of the rise in metal oxidation reaction rate. The latter case will result in a noble shift because of the increase in oxidant species supply, promoting the cathodic reaction. In this study, the OCP was shifted towards the active direction, so the first effect was the prevailing one. However, after the OCP test, the electrode surface did not show any sign of physical damage or corrosion (Figure $\mathbf{2 a}$ and $\mathbf{2 b}$ ), so cavitation could not break the passive film formed on the electrode surface, but it reduced its thickness, favouring the anodic reaction. 
In the potentiodynamic curve, the increment of the cathodic current densities under cavitation conditions was due to the rise in oxidant species transport towards the electrode surface, which produced a shift in the corrosion potential $\left(E_{c o r r}\right)$ to nobler values (Table 2). Nevertheless, the difference between the values of $E_{c o r r}$ under static and cavitation conditions was very small (only $70 \mathrm{mV}$ ), so this parameter will not be used to discuss the corrosion behaviour of alloy 31 under cavitation conditions; instead, only OCP values are considered in this analysis. Concerning the rise of $i_{\text {corr }}$ under cavitation conditions (Table 2), it was because of the displacement of both cathodic and anodic braches to higher current densities values; the increase of $i_{c o r r}$ could also have been caused by the thinning of the passive layer [55].

The increase in the passive current density due to the influence of cavitation (Table 2) can be related to the reduction of the passive film thickness [55]. Besides, cavitation can make the diffusion layer thinner [14]. During anodic polarization, soluble corrosion products were formed on the corroding surface. These ions diffused towards the solution bulk, and a concentration gradient appeared in the diffusion layer next to the electrode. As the metal dissolution rate increased, the concentration of corrosion products increased too, and eventually the saturation concentration was reached, leading to precipitation of a solid film (passive film). Under static conditions, the thickness of passive film did not vary. However, in the presence of cavitation, the film thickness was decreased by the implosion of bubbles near the electrode. Moreover, the collapse of bubbles reduced the thickness of the diffusion layer, so the passive current density increased as a result of activated electrochemical dissolution $[14,17]$. 
The reduction of the passive zone range $\left(E_{p}-E_{c o r r}\right)$ in the presence of cavitation (Table 2) in the potentiodynamic curve was caused by the decrease of the pitting potential, $E_{p}$. This decrease of $E_{p}$ was related to the higher passive current densities which were recorded under cavitation conditions, which made the stability of the film and its protective properties be lesser with cavitation than without it. Consequently, the presence of cavitation caused the passive film breakdown to take place at lower potentials (lower $E_{p}$ ).

Current density increased more sharply after reaching the pitting potential under static conditions than under cavitation ones (Figure 3). This difference was produced by two factors. On the one hand, cavitation removed the rests of the passive layer which covered the pits [18]. This removal avoided the pit inside from being isolated and decreased the local concentration of $\mathrm{Br}^{-}$and $\mathrm{H}^{+}$ions, which made the pit propagation more difficult. Furthermore, the corrosion products had a catalytic effect on the pit growth; then, the removal of these products due to the mechanical action of the collapsing cavities diminished the metal dissolution [56].

The reduction of the repassivation current density, $i_{r p}$ (Table 2), was due to the localized turbulent stirring of the solution induced by the implosion of bubbles [14].

The hysteresis loop $\left(E_{p}-E_{r p}\right)$ was smaller under cavitation conditions (Table 2). This was despite the fact that $E_{p}$ was lower. As a rule, the wider the hysteresis loop, the worse is the regeneration of the damaged passive film [20,39,42]. Thus, although the value of $E_{p}$ with cavitation is lower than without it, which implies a lower pitting 
corrosion resistance, the repassivation of Alloy 31 is easier under cavitation conditions than under static conditions once pitting occurs, since the hysteresis loop width is lower in the former case.

Regarding the attack morphology without cavitation in the potentiodynamic tests (Figure 4), the corrosion products generated at localized sites changed the conditions around them, and catalyzed the corrosion phenomenon. Other authors have obtained similar results $[8,14,43]$. With cavitation, the attack morphology showed the clear development of pits (Figure 5). The mechanical action of the collapsing cavities removes the corrosion products on the electrode surface, avoiding them from spreading the damage on the surface, which made attack more localized [14,56].

The difference in the damaged area extent with and without cavitation is highly significant. The damaged area was 100 times higher under static conditions than under cavitation conditions. This can be explained analyzing the area under the hysteresis loop in both cases (Figure 3). In the presence of cavitation, this area under the loop was lower than without it, which evidences that cavitation enhances the repassivation behaviour of Alloy 31, although the passive film formed under these conditions is less stable and less protective. In addition, since the collapsing bubbles constantly remove the corrosion products (which have a catalytic effect), the damage propagation is much more difficult than under static conditions $[14,56]$.

\section{Repassivation behaviour}


In Figure 7a, a rise in the current density was recorded when connecting cavitation. This rise was sharp at $200 \mathrm{mV}_{\mathrm{Ag} / \mathrm{AgCl}}$; at $-400 \mathrm{mV} \mathrm{Ag} / \mathrm{AgCl}$ and $-200 \mathrm{mV} \mathrm{Ag}_{\mathrm{AgCl}}$, many current density transients were discerned. This indicates that the passive film of Alloy 31 was being physically broken, and the fresh surface was corroding.

After disconnecting cavitation, for the $-400 \mathrm{mV}$ Ag/AgCl and $-200 \mathrm{mV}_{\mathrm{Ag} / \mathrm{AgCl}}$ tests, the current density decreased abruptly to values lower than before the physical breakdown (Figure 7c). This shows that the properties of the regenerated passive film are better than those of the original passive film. These properties are improved with immersion time of Alloy 31 in the solution because of the growth of a passive film on the electrode surface during immersion time, containing $\mathrm{Cr}_{2} \mathrm{O}_{3}$ as well as iron oxide, iron and nickel $[22,43]$.

For the $0 \mathrm{mV}_{\mathrm{Ag} / \mathrm{AgCl}}$ test, the rise in current density after disconnecting cavitation suggests that the Alloy 31 surface cannot be repassivated correctly at this potential (Figure 8). At $200 \mathrm{mV} \mathrm{Ag} / \mathrm{AgCl}$, the increment in current density, as well as the increment at $0 \mathrm{mV}$ Ag/AgCl, can be attributed to pit growth [31,32]. Thus, at potentials between the values of $E_{r p}$ and $E_{p}$ (unstable passivity region) for Alloy 31 in the $992 \mathrm{~g} / 1 \mathrm{LiBr}$ solution, bubbles collapse is enough to damage the metal surface, creating pits that will manage to propagate and become stable. 
Logarithmic curves $\log i(t) v s . \log t$

In Figure 9 it can be observed that at $0 \mathrm{mV}_{\mathrm{Ag} / \mathrm{AgCl}}$ and $200 \mathrm{mV} \mathrm{Ag}_{\mathrm{AgCl}}$, the anodic current density $(i)$ in the first section was almost constant, although as potential was increased, this first stage was longer. It is noteworthy that at $0 \mathrm{mV}_{\mathrm{Ag} / \mathrm{AgCl}}$ and $200 \mathrm{mV}_{\mathrm{Ag} / \mathrm{AgCl}}$ there were barely any differences between the first and the second stage. In this first stage, the rate of passive film formation was similar to the rate of passive film destruction [29]; as a consequence, the passive film hardly grew and the damaged surface was barely repassivated. For the $-400 \mathrm{mV}_{\mathrm{Ag} / \mathrm{AgCl}}$ and $-200 \mathrm{mV} \mathrm{Ag} / \mathrm{AgCl}$ tests, the current density suffers a transient in this first stage, becoming linear with time in the next stage.

In the second stage, the anodic current density linearly decreased with time in logarithmic scale. This descent was more evident at $-400 \mathrm{mV} V_{\mathrm{Ag} / \mathrm{AgCl}}$ and $-200 \mathrm{mV} \mathrm{Ag} / \mathrm{AgCl}$, whereas at higher potentials it was scarcely detected. The current density drop was due to the fact that the rate of passive film regeneration prevailed over its rate of destruction [29-31]. It is generally accepted that the fast descent of current density is caused by the high rates of passive film formation and growth upon the metal surface [29]. Thus, at lower potentials (-400 $\mathrm{mV}_{\mathrm{Ag} / \mathrm{AgCl}}$ and $\left.-200 \mathrm{mV} \mathrm{Ag} / \mathrm{AgCl}\right)$, the repassivation rate is higher than at $0 \mathrm{mV}_{\mathrm{Ag} / \mathrm{AgCl}}$. At $200 \mathrm{mV} \mathrm{Ag} / \mathrm{AgCl}$ there was no practical repassivation.

In the third stage, the current density value remained approximately constant at -400 $\mathrm{mV}_{\mathrm{Ag} / \mathrm{AgCl}}$ and $-200 \mathrm{mV} \mathrm{Ag}_{\mathrm{AgCl}}$, which indicates that a steady state between the rates of passive film formation and passive film destruction was reached. Fluctuations that are observed towards the end of this third stage may be due to the formation and following repassivation of metastable pitting [29,38,49,50]. For $200 \mathrm{mV} \mathrm{Ag} / \mathrm{AgCl}$, the current density 
record tended to rise with time. This increase can be due to both passive film local breakdown and stable pits growth, even at potentials below the pitting potential, $E_{p}$ [2932].

Table 3 gathers the results obtained from Figure 9: as the applied potential increases, the passive film repassivates more slowly after being damaged by cavitation. The repassivation index is not higher than 1 in any case, which is usually related to the formation of a compact high protective passive film, and would indicate a very fast repassivation $[51,57,58]$. Values of $n$ lower than 0.5 indicate the presence of a porous passive film [51] and a relatively slow repassivation rate [57,59]. For $200 \mathrm{mV} \mathrm{Ag}_{\mathrm{AgCl}}$, the parameter $n$ has not been calculated, since no repassivation is observed at this potential. Instead, the parameter $b$ has been calculated, which describes the pit growth kinetics. The value of this parameter is rather small if compared with the values of $n$ at $-400 \mathrm{mV}$ and $-200 \mathrm{mV}$, which indicates that the growing of the pits formed on the electrode surface at $200 \mathrm{mV}$ was slow.

The damages generated during the potentiostatic tests (Figure 10) are due to the synergistic effect that exists between cavitation and corrosion [10-13]. According to the passivity region (perfect or unstable), the damage generated during the potentiostatic tests is different, as results in Table 4 show. At the perfect passivity region potentials ($400 \mathrm{mV}_{\mathrm{Ag} / \mathrm{AgCl}}$ and $-200 \mathrm{mV} \mathrm{Ag}_{\mathrm{AgCl}}$ ), theoretically pits cannot develop, so the damage produced is mainly due to cavitation. At elevated potentials $\left(0 \mathrm{mV}_{\mathrm{Ag} / \mathrm{AgCl}}\right.$ and 200 $\mathrm{mV}_{\mathrm{Ag} / \mathrm{AgCl}}$ ), the physical damage may grow as a stable pit (these potentials are located in the unstable passivity region), since as the applied potential increases the repassivation 
rate gets smaller. In the extreme case, the repassivation index would become zero, and the passive film could not regenerate.

In order to determine only the physical damage produced on the Alloy 31 surface, a test was performed in distilled water, applying cavitation for 60 seconds. Supposing that the generated damages in distilled water and in the $992 \mathrm{~g} / \mathrm{l} \mathrm{LiBr}$ solution have circular shapes, Figure 12 illustrates the areas of maximum depth for both cases (the inner circle for distilled water and the outer circle for $992 \mathrm{~g} / \mathrm{L} \mathrm{LiBr}$ solution (Figure 10)). It can be noticed that at $-400 \mathrm{mV}_{\mathrm{Ag} / \mathrm{AgCl}}$, the damaged areas are practically the same, so cavitation is the only responsible for the damage in the $992 \mathrm{~g} / \mathrm{LiBr}$ solution. At $-200 \mathrm{mV} \mathrm{Ag}_{\mathrm{AgCl}}$, although this potential is in the perfect passivity region, cavitation-corrosion phenomena took place, since the damaged area in distilled water is lower than that in the $992 \mathrm{~g} / \mathrm{l}$ $\mathrm{LiBr}$ solution, indicating that damage propagation occurred. Nevertheless, the propagation rate is lower than at $0 \mathrm{mV}_{\mathrm{Ag} / \mathrm{AgCl}}$ and $200 \mathrm{mV}_{\mathrm{Ag} / \mathrm{AgCl}}$ (Figure 12), which are in the unstable passivity region.

\section{CONCLUSIONS}

Ultrasonically induced cavitation was found to shift the Open Circuit Potential of Alloy 31 in the $992 \mathrm{~g} / 1 \mathrm{LiBr}$ solution towards the active direction, because the effect ofcavitation reduced the thickness of the passive film, favouring the anodic reaction. However, there was no physical damage on the electrode surface after the OCP test, so cavitation could not break the passive film. 
Cavitation increased the passive current density, due to the thinning of the passive film that covered the alloy surface.

The $E_{p}$ of Alloy 31 in the $992 \mathrm{~g} / 1 \mathrm{LiBr}$ solution decreased under cavitation conditions. Moreover, the extent of the passive region decreased with cavitation, revealing that this phenomenon negatively affects the corrosion behaviour of Alloy 31 in the $992 \mathrm{~g} / 1 \mathrm{LiBr}$ solution. However, the area under the hysteresis loop was lower in presence of cavitation than without it, which implies that cavitation improves the repassivation behaviour of Alloy 31 in $992 \mathrm{~g} / 1 \mathrm{LiBr}$ solutions.

The attack morphology was different depending on the conditions. Under static conditions, the morphology of the damage generated on the electrode surface was uniform (although the initial mechanism was pitting corrosion), whereas under cavitation conditions, the attack was localized and visible pits appeared on the surface. This pits are dangerous, because they can be deep enough to perforate the material.

The parameter $n$, determined from the slopes of the $\log i(t)$ vs. $\log t$ were found to increase with decreasing applied potentials, indicating that repassivation is faster at potentials located in the perfect passivity region than at potentials of the unstable passivity region. At potentials near the pitting potential $\left(200 \mathrm{mV}_{\mathrm{Ag} / \mathrm{AgCl}}\right)$, repassivation is not possible.

The quantification of the generated damage on the Alloy 31 surface in $992 \mathrm{~g} / 1 \mathrm{LiBr}$ solution, during potentiostatic tests, by cavitation-corrosion using Confocal Laser Microscopy and image analysis techniques showed that the volume, surface area and 
depth of these damages increased with increasing potentials. Moreover, a linear relationship between the damaged area and the applied potential was obtained.

\section{ACKNOWLEDGEMENTS}

We wish express our gratitude to the Ministerio de Ciencia e Innovación (Project CTQ2009-07518), for the economical support of this research, to the Generalitat Valenciana for its help in the CLSM acquisition (MY08/ISIRYM/S/100), to Thyssen Krupp for supplying the materials, and to Dr. M. Asunción Jaime for her translation assistance.

\section{REFERENCES}

[1] American Society of Heating, Refrigerating and Air-Conditioning Engineers (ASHRAE) Handbook, Absorption Cooling, Heating and Refrigeration Equipment (Refrigeration Volume), 2002.

[2] A. Igual-Muñoz, J. García-Antón, J. L. Guiñón, V. Pérez-Herranz, Corrosion 59 (2003) 606-615.

[3] J. L. Guiñón, J. García-Antón, V. Pérez-Herranz, G. Lacoste, Corrosion 50 (1994) 240-248.

[4] A. Igual-Muñoz, J. García-Antón, J. L. Guiñón, V. Pérez-Herranz, Corrosion 59 (2003) 32-41.

[5] E. A. Abd El Meguid, N. K. Awad, Corrosion Sci. 51 (2009) 1134-1139. 
[6] M. J. Muñoz-Portero, J. García-Antón, J. L. Guiñón, V. Pérez-Herranz, Corrosion 62 (2006) 1018-1027.

[7] D. Itzhak, O. Elias, Corrosion 50 (1994) 131-137.

[8] E. Blasco-Tamarit, A. Igual-Muñoz, J. García-Antón, D. García-García, Corrosion Sci. 50 (2008) 1848-1857.

[9] E. Blasco Tamarit, A. Igual Muñoz, J. García Antón, D. García García, Corrosion Sci. 49 (2007) 1000-1026.

[10] J. P. Franc (Ed.), J. M. Michel (Ed.), Fundamentals of Cavitation, Kluwer Academic Publishers, $1^{\text {st }}$ edition, 2004.

[11] C. T. Kwok, F. T. Cheng, H. C. Man, Materials Science and Engineering A 290 (2000) 145-154.

[12] H. X. Guo, B. T. Lu, J. L. Luo, Electrochim. Acta 51 (2005) 315-323.

[13] C. H. Tang, F. T. Cheng, H. C. Man, Materials Science and Engineering A 373 (2004) 195-203.

[14] D. M. García-García, J. García-Antón, A. Igual-Muñoz, E. Blasco-Tamarit, Corrosion Sci. 48 (2006) 2380-2405.

[15] A. Neville, B. A. B. McDougall, Wear 250 (2001) 726-735.

[16] A. Al-Hashem, P. G. Caceres, W. T. Riad, H. M. Shalaby, Corrosion 51 (1995) 331-342.

[17] A. Al-Hashem, P. G. Caceres, A. Abdullah, H. M. Shalaby, Corrosion 53 (1997) 103-113. 
[18] R. Wang, M. Kido, Corrosion Sci. 51 (2009) 1604-1610.

[19] D. M. García García, J. García Antón, A. Igual Muñoz, Corrosion Sci. 50 (2008) $2560-2571$.

[20] T. Bellezze, G. Roventi, R. Fratesi, Electrochim. Acta 49 (2004) 3005-3014.

[21] M. Kaneko, H. S. Isaacs, Corrosion Sci. 42 (2000) 67-78.

[22] G. Lothongkum, S. Chaikittisilp, A. W. Lothongkum, Applied Surface Science 218 (2003) 203-210.

[23] A. A. Hermas, K. Ogura, S. Takagi, T. Adachi, Corrosion 51 (1995) 3-10.

[24] E. A. Abd El Meguid, N. A. Mahmoud, Corrosion 59 (2003) 104-111.

[25] M Kaneko, H. S. Isaacs, Corrosion Science 44 (2002) 1825-1834.

[26] J. R. Hayes, J. J. Gray, A. W. Szmodis, C. A. Orme, Corrosion 62 (2006) 491-500.

[27] R. C. Newman, Corrosion 57 (2001) 1030-1041.

[28] C. O. A. Olsson, D. Landolt, Electrochim. Acta 48 (2003) 1093-1104.

[29] J. J. Park, S. I. Pyun, W. J. Lee, H. P. Kim, Corrosion 55 (1999) 380-387.

[30] J. B. Lee, Materials Chemistry and Physics 99 (2006) 224-234.

[31] J. D. Kim, S. I. Pyun, Electrochim. Acta 40 (1995) 1863-1869.

[32] S. I. Pyun, E. J. Lee, Electrochim. Acta 40 (1995) 1963-1970.

[33] G. T. Burstein, P. I. Marshall, Corrosion Sci. 23 (1983) 125-137.

[34] M. Barbosa, J. C. Scully, Corrosion Sci. 22 (1982) 1025-1036. 
[35] E. A. Cho, C. K. Kim, J. -S. Kim, H. -S. Kwon, Electrochim. Acta 45 (2000) 1933-1942.

[36] H. S. Kwon, E. A. Cho, K. A. Yeom, Corrosion 56 (2000) 32-40.

[37] J. S. Kim, P. J. Xiang, K. Y. Kim, Corrosion 61 (2005) 174-183.

[38] S. Ahila, B. Reynders, H. J. Grabke, Corrosion Sci. 38 (1996) 1991-2005.

[39] J. García-Antón, A. Igual-Muñoz, J. L. Guiñón, V. Pérez-Herranz, Spain, P$200002525,2000$.

[40] J. García-Antón, A. Igual-Muñoz, J. L. Guiñón, V. Pérez-Herranz, Spain, P200002526, 2000.

[41] ASTM G-5, Test Method for Making Potentiostatic and Potentiodynamic Anodic Polarization Measurements, American Society for Testing and Materials, 2004.

[42] S. D. Cramer (Ed.), B. S. Covino, Jr. (Ed.), Corrosion: Fundamentals, Testing and Protection, Vol. 13A, ASM Handbook, ASM International, 2003.

[43] E. Blasco-Tamarit, A. Igual-Muñoz, J. García-Antón, Corrosion Sci. 49 (2007) $4452-4471$.

[44] C. T. Kwok, H. C. Man, F. T. Cheng, Materials Science and Engineering A 303 (2001) 250-261.

[45] G. O. H. Whillock, B. F. Harvey, Ultrasonics Sonochemistry 3 (1996) S111-S118.

[46] R. Leiva-García, M. J. Muñoz-Portero, J. García-Antón, Corrosion Sci. (2009) In Press.

[47] G. S. Frankel, L. Stockert, F. Hunkeler, H. Boehni, Corrosion, 43(1987) 429-436. 
[48] A. Pardo, E. Otero, M.C. Merino, M.D. López, M.V. Utrilla, F. Moreno, Corrosion $56(2000) 411-418$.

[49] G. O. Ilevbare, G. T. Burstein, Corrosion Sci. 45 (2003) 1545-1569.

[50] G. T. Burstein, C. Liu, R. M. Souto, Biomaterials 26 (2005) 245-256.

[51] M. Lakatos-Varsányi, F. Falkenberg, I. Olefjord, Electrochim. Acta 43 (1997) 187197.

[52] A. Neville, T. Hodgkiess, J. T. Dallas, Wear 186-187 (1995) 497-507.

[53] S. Z. Luo, Y. G. Zheng, M. C. Li, Z. M. Yao, W. Ke, Corrosion 59 (2003) 597-605.

[54] S. L. Jiang, Y. G. Zheng, Z. M. Yao, Corrosion Sci. 48 (2006) 2614-2632.

[55] W. Bao-Cheng, Z. Jin-hua, Ultrasonics Sonochemistry 15 (2008) 239-243.

[56] D. M. García García, Influencia de la cavitación sobre el comportamiento electroquímico de soldaduras de aceros inoxidables dúplex en máquinas de absorción de LiBr mediante técnicas electroquímicas y de análisis de imagen, Ph.D. Thesis, Universidad Politécnica de Valencia (2007).

[57] R. M. Carranza, J. R. Galvele, Corrosion Sci. 28 (1988) 233-249.

[58] E. Otero Huerta, Corrosión y Degradación de Materiales, Síntesis, $1^{\text {st }}$ edition, 1997.

[59] R. M. Carranza, J. R. Galvele, Corrosion Sci. 28 (1988) 851-865. 
$\underline{\text { Tables }}$

Table 1. OCP values for Alloy 31 in $992 \mathrm{~g} / 1 \mathrm{LiBr}$ solution under static $(p p A=0 \mu m)$ and cavitation $(p p A$ $=120 \mu \mathrm{m})$ conditions.

\begin{tabular}{|c|c|c|}
\hline \multicolumn{3}{|c|}{ OCP $(\mathrm{mV}$ Ag/AgCl $)$} \\
\hline$p p A=0 \mu \mathrm{m}$ & $p p A=120 \mu \mathrm{m}$ & $\Delta$ OCP \\
\hline$-248 \pm 8$ & $-956 \pm 32$ & 708 \\
\hline
\end{tabular}

Table 2. Electrochemical parameters for Alloy 31 in $992 \mathrm{~g} / 1 \mathrm{LiBr}$ solution under static $(p p A=0 \mu m)$ and cavitation $(\mathrm{ppA}=120 \mu \mathrm{m})$ conditions.

\begin{tabular}{|c|c|c|c|c|c|c|c|c|}
\hline & $\begin{array}{c}E_{\text {corr }} \\
\left(V_{\text {Ag/AgC }}\right. \\
\text { l) }\end{array}$ & $\begin{array}{c}E_{p} \\
\left(V_{\text {Ag/AgC }}\right. \\
\text { l) }\end{array}$ & $\begin{array}{c}E_{r p} \\
\left(V_{\text {Ag/AgC }}\right. \\
\text { l) }\end{array}$ & $\begin{array}{l}E_{r p}- \\
E_{c o r r}\end{array}$ & $E_{p}-E_{r p}$ & $\begin{array}{c}i_{\text {corr }} \\
(\mu \mathrm{A} / \mathrm{cm} \\
2)\end{array}$ & $\begin{array}{c}i_{p} \\
(\mu \mathrm{A} / \mathbf{c} \\
\left.\mathbf{m}^{2}\right)\end{array}$ & $\begin{array}{c}i_{r p} \\
\left(\mathrm{~A} / \mathbf{c m}^{2}\right)\end{array}$ \\
\hline $\begin{array}{c}p p A=0 \\
\mu \mathrm{A}\end{array}$ & $\begin{array}{c}-0.770 \pm \\
0.005\end{array}$ & $\begin{array}{c}0.533 \pm \\
0.011\end{array}$ & $\begin{array}{c}-0.061 \pm \\
0.013\end{array}$ & $\begin{array}{c}0.709 \pm \\
0.018\end{array}$ & $\begin{array}{c}0.595 \pm \\
0.023\end{array}$ & $\begin{array}{c}0.75 \pm \\
0.01\end{array}$ & $\begin{array}{c}2.36 \pm \\
0.09\end{array}$ & $\begin{array}{c}0.023 \pm \\
0.002\end{array}$ \\
\hline $\begin{array}{c}p p A= \\
120 \mu \mathrm{A}\end{array}$ & $\begin{array}{c}-0.700 \pm \\
0.037\end{array}$ & $\begin{array}{c}0.321 \pm \\
0.019\end{array}$ & $\begin{array}{c}-0.030 \pm \\
0.008\end{array}$ & $\begin{array}{c}0.671 \pm \\
0.044\end{array}$ & $\begin{array}{c}0.350 \pm \\
0.028\end{array}$ & $\begin{array}{c}1.79 \pm \\
0.04\end{array}$ & $\begin{array}{c}12.78 \pm \\
2.49\end{array}$ & $\begin{array}{c}0.013 \pm \\
0.001\end{array}$ \\
\hline
\end{tabular}

Table 3. Values of the parameters $n$ and $b$, obtained from the linear region slope of $\log (\mathrm{t})$ vs $\log \mathrm{i}(\mathrm{t})$ representation, for Alloy 31 in $992 \mathrm{~g} / 1 \mathrm{LiBr}$ solution.

\begin{tabular}{|c|c|c|c|}
\hline Potential (mV $\mathbf{\text { Ag/AgCl}} \mathbf{)}$ & $\boldsymbol{n}$ & $\boldsymbol{b}$ & $\mathbf{R}^{\mathbf{2}}$ \\
\hline-400 & 0.647 & ----- & 0.84 \\
\hline-200 & 0.307 & ---- & 0.91 \\
\hline 0 & 0.064 & ----- & 0.95 \\
\hline 200 & ----- & 0.104 & 0.79 \\
\hline
\end{tabular}


Table 4. Parameters of the damage created by cavitation-corrosion on the Alloy 31 surfaces in $992 \mathrm{~g} / \mathrm{l}$ $\mathrm{LiBr}$ solutions, at different applied potentials (the values are mean values).

\begin{tabular}{|c|c|c|c|}
\hline $\begin{array}{l}\text { Potential } \\
\left(\mathrm{V}_{\mathrm{Ag} / \mathrm{AgCl}}\right)\end{array}$ & $\begin{array}{c}\text { Volume } \cdot 10^{7} \\
\left(\mu \mathrm{m}^{3}\right)\end{array}$ & $\begin{array}{c}\text { Lateral surface area } \cdot 10^{6} \\
\left(\mu \mathrm{m}^{2}\right)\end{array}$ & $\begin{array}{c}\text { Maximum depth } \\
(\mu \mathrm{m})\end{array}$ \\
\hline-0.4 & $3.89 \pm 0.61$ & $1.24 \pm 0.18$ & $13.79 \pm 0.62$ \\
\hline-0.2 & $5.93 \pm 0.69$ & $1.67 \pm 0.29$ & $15.27 \pm 1.21$ \\
\hline 0.0 & $15.88 \pm 1.33$ & $23.40 \pm 2.18$ & $48.96 \pm 2.39$ \\
\hline 0.2 & $51.80 \pm 2.41$ & $38.40 \pm 2.73$ & $88.13 \pm 4.11$ \\
\hline
\end{tabular}


$\underline{\text { Figures }}$

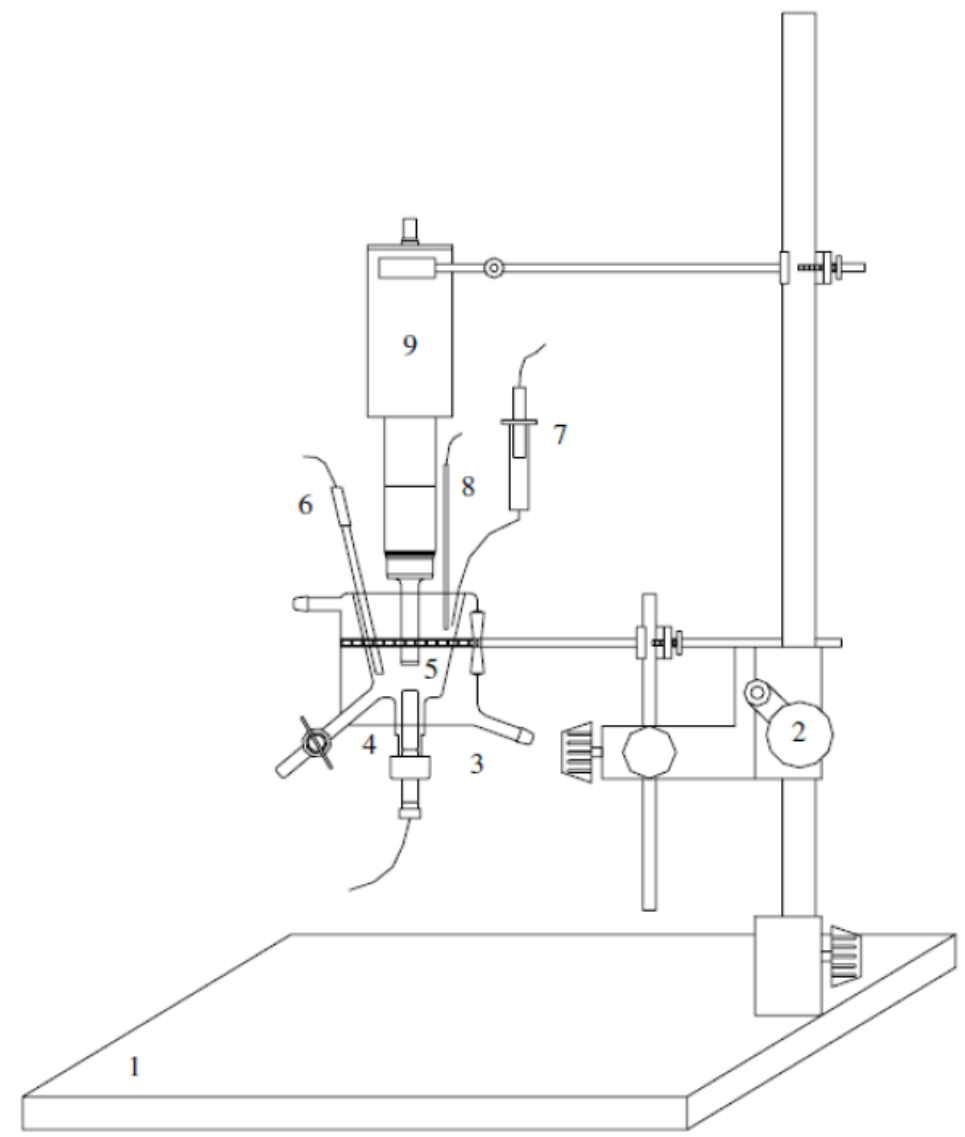

Fig. 1. Experimental arrangement diagram used for cavitation testing: (1) base of experimental arrangement; (2) height adjustment; (3) electrochemical cell; (4) working electrode; (5) horn tip; (6) auxiliary electrode (platinum mesh); (7) reference electrode ( $\mathrm{Ag} / \mathrm{AgCl}$ with $3 \mathrm{M} \mathrm{KCl}$ solution); (8) temperature sensor; (9) convertor of ultrasonic cavitation facility. 


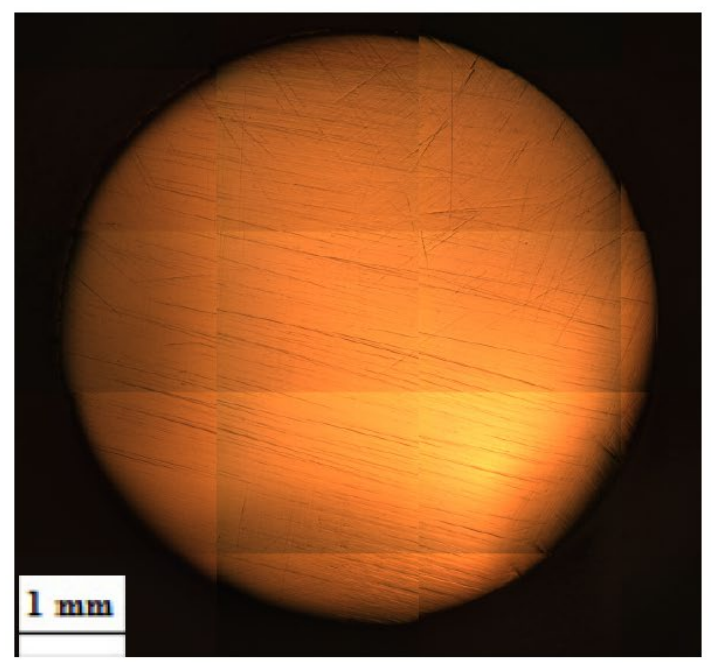

a. Initial mosaic (sample diameter $=8 \mathrm{~mm}$ )

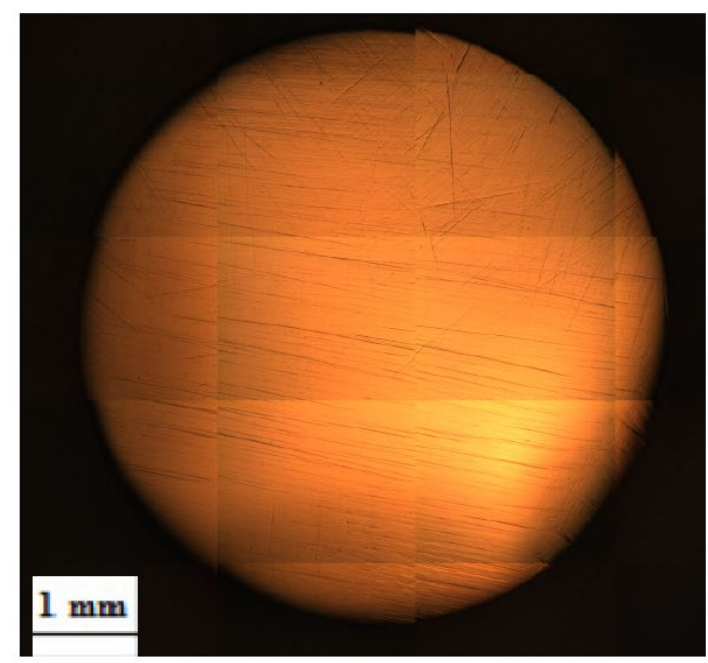

a. Final mosaic (sample diameter $=8 \mathrm{~mm}$ )

Fig. 2. Images of the electrode surface before (a) and after (b) the OCP test with cavitation.

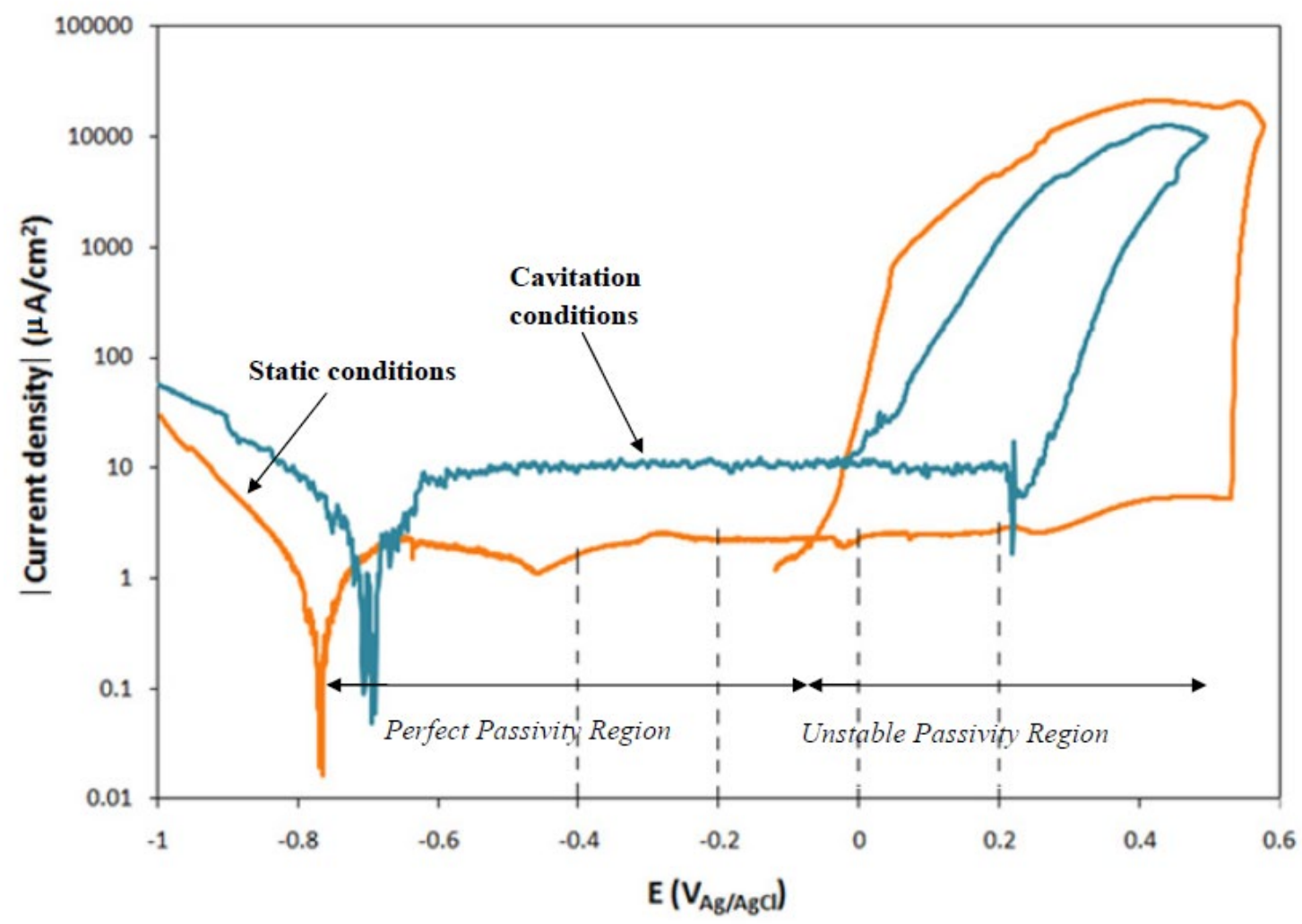

Fig. 3. Potentiodynamic polarization cyclic curves for Alloy 31 in 992 g/l LiBr solution under static and cavitation conditions. This figure also shows the two passivity region (Perfect Passivity Region and Unstable Passivity Region) under static conditions, and the potentials chosen to perform the potentiostatic tests. 


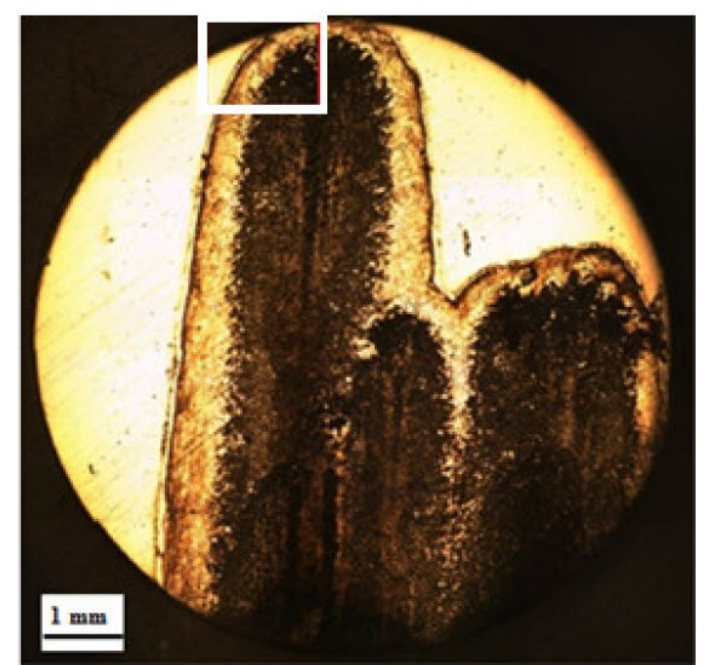

a. Initial mosaic (sample diameter $=8 \mathbf{~ m m}$ )

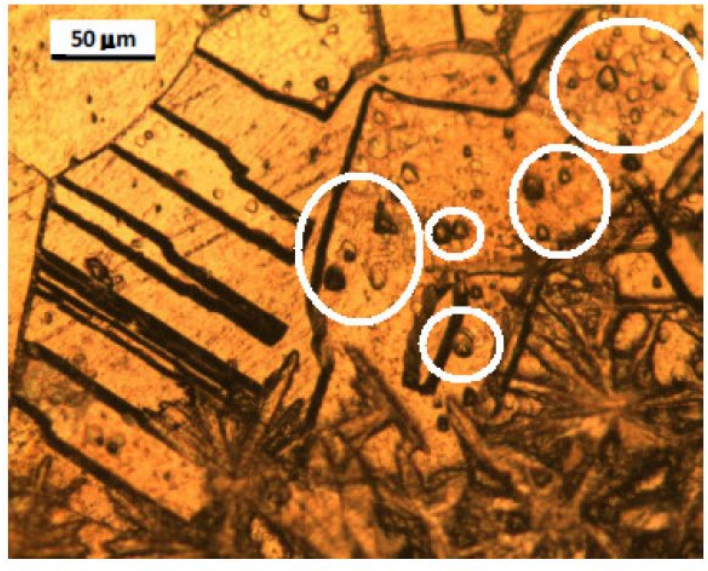

b. Magnified zone

Fig. 4. Images of Alloy 31 in $992 \mathrm{~g} / \mathrm{l} \mathrm{LiBr}$ solution at the end of the potentiodynamic cyclic test, under static conditions (taken using an Optic Microscope). In the magnified image (b), small round pits can be discerned.

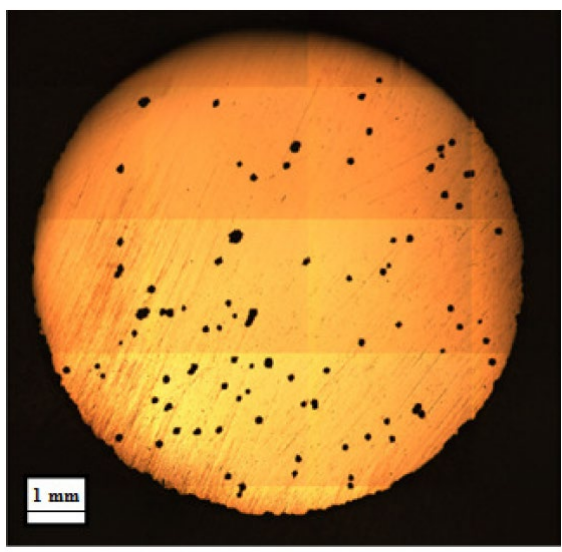

Fig. 5. Final mosaic of Alloy 31 surface in $992 \mathrm{~g} / \mathrm{LiBr}$ solution at the end of the potentiodynamic cyclic test, under cavitation conditions (taken using an Optic Microscope) (sample diameter $=8 \mathrm{~mm}$ ). 

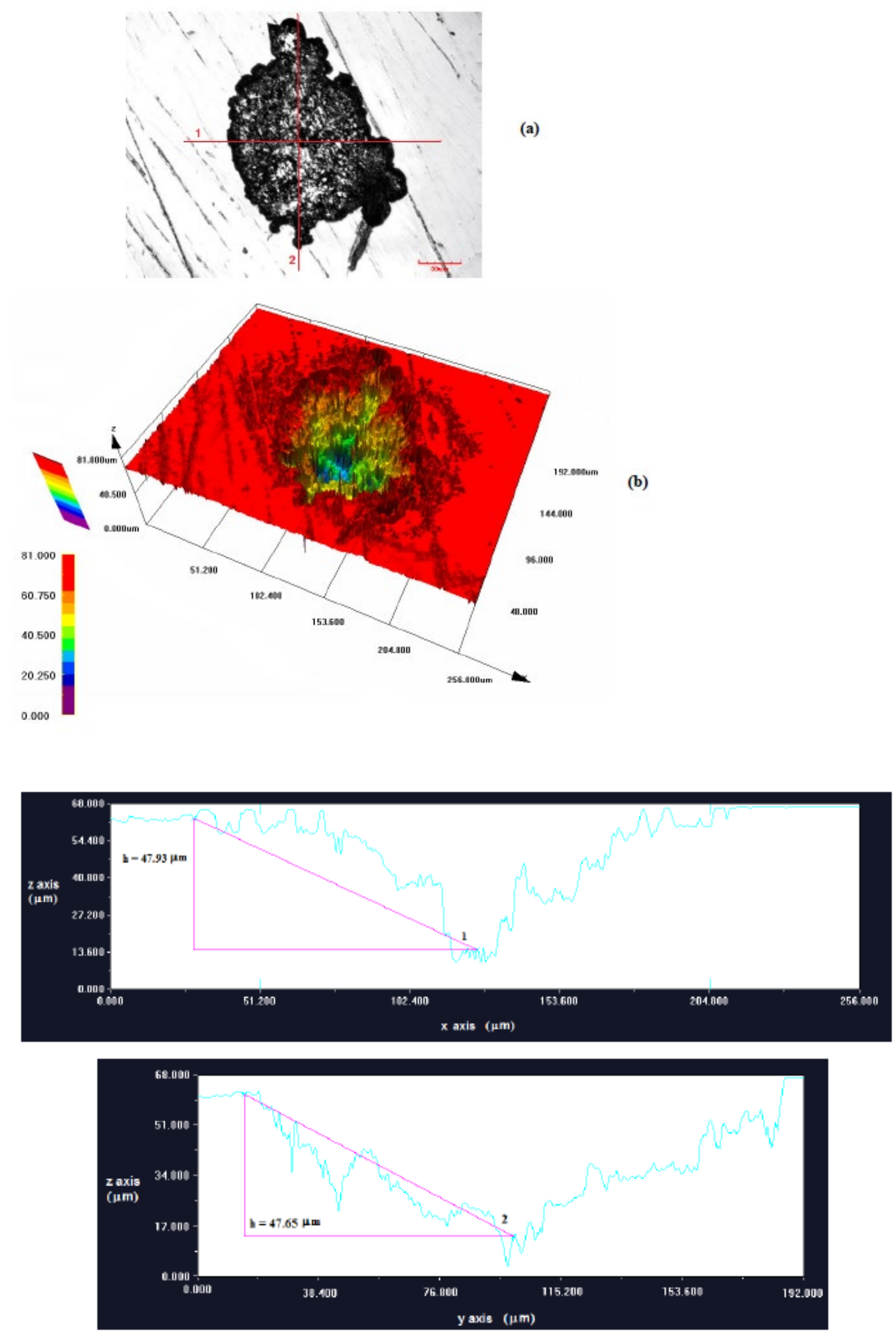

(c) 
Fig. 6. Image of Alloy 31 pit in $992 \mathrm{~g} / 1 \mathrm{LiBr}$ solution, at 500x, under cavitation conditions (taken using the Confocal Laser Microscope), (a) in 2D, (b) in 3D, (c) profiles of Alloy 31 pit in $992 \mathrm{~g} / 1 \mathrm{LiBr}$ solution, under cavitation conditions.

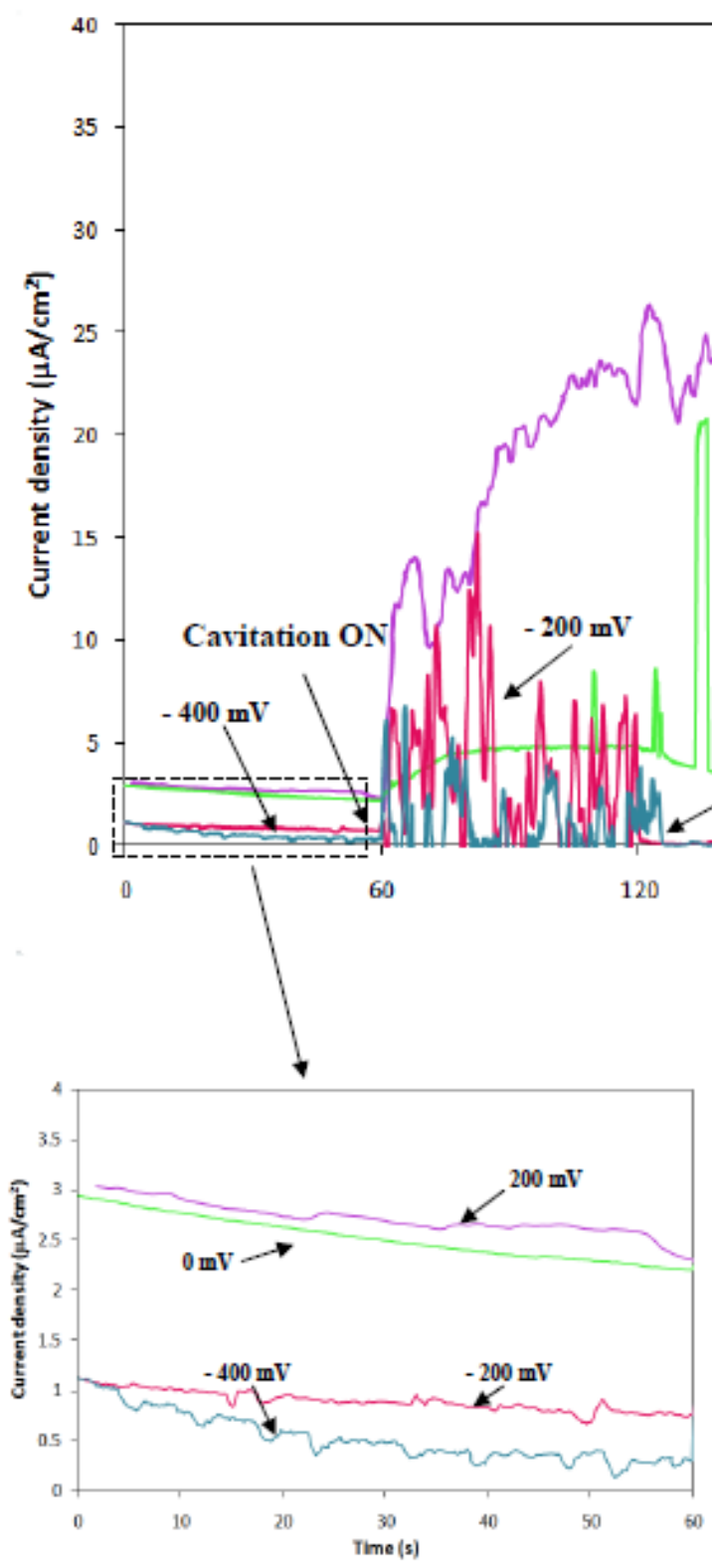

(b)

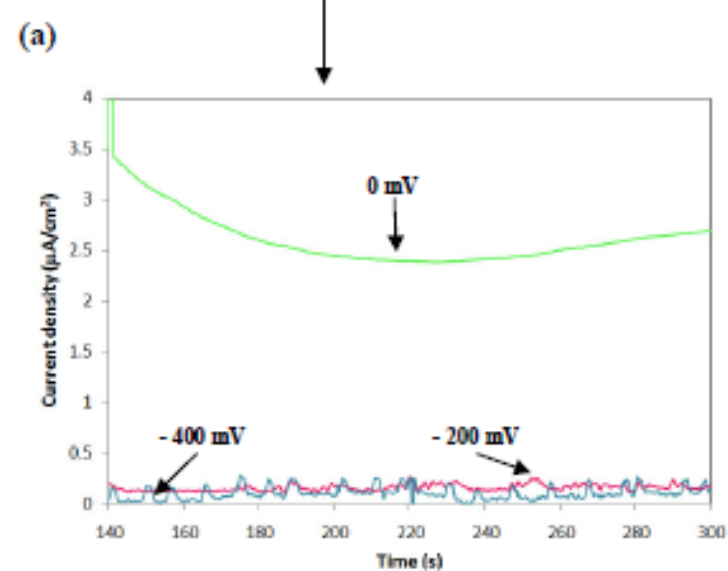

(c)

Fig. 7. Current density transients in linear scale for Alloy 31 in $992 \mathrm{~g} / \mathrm{l} \mathrm{LiBr}$ solution at the four selected potentials. 


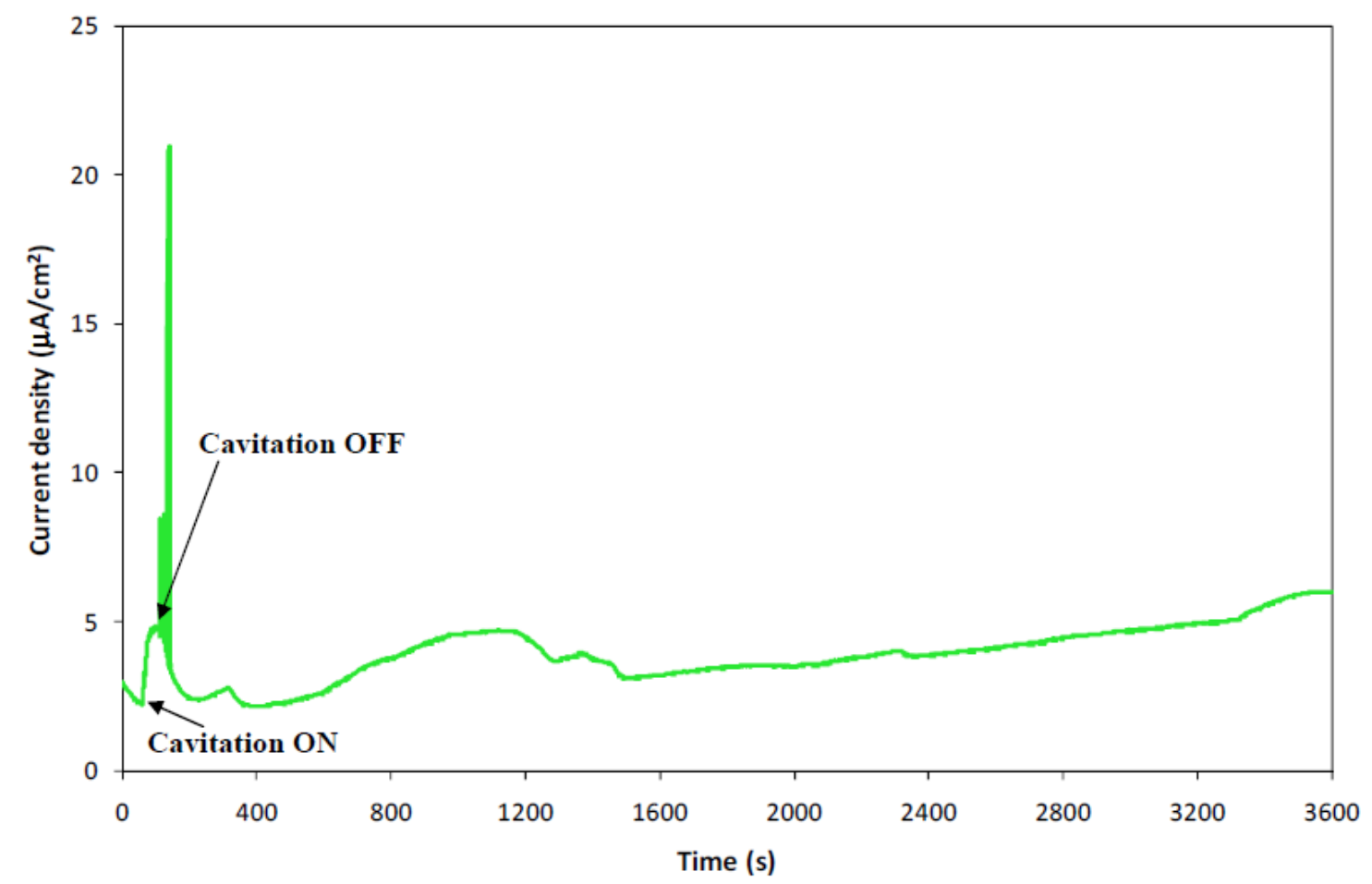

Fig. 8. Current density transient in linear scale for Alloy 31 in $992 \mathrm{~g} / \mathrm{LiBr}$ solution at $0 \mathrm{mV} \mathrm{Ag} / \mathrm{AgCl}$.

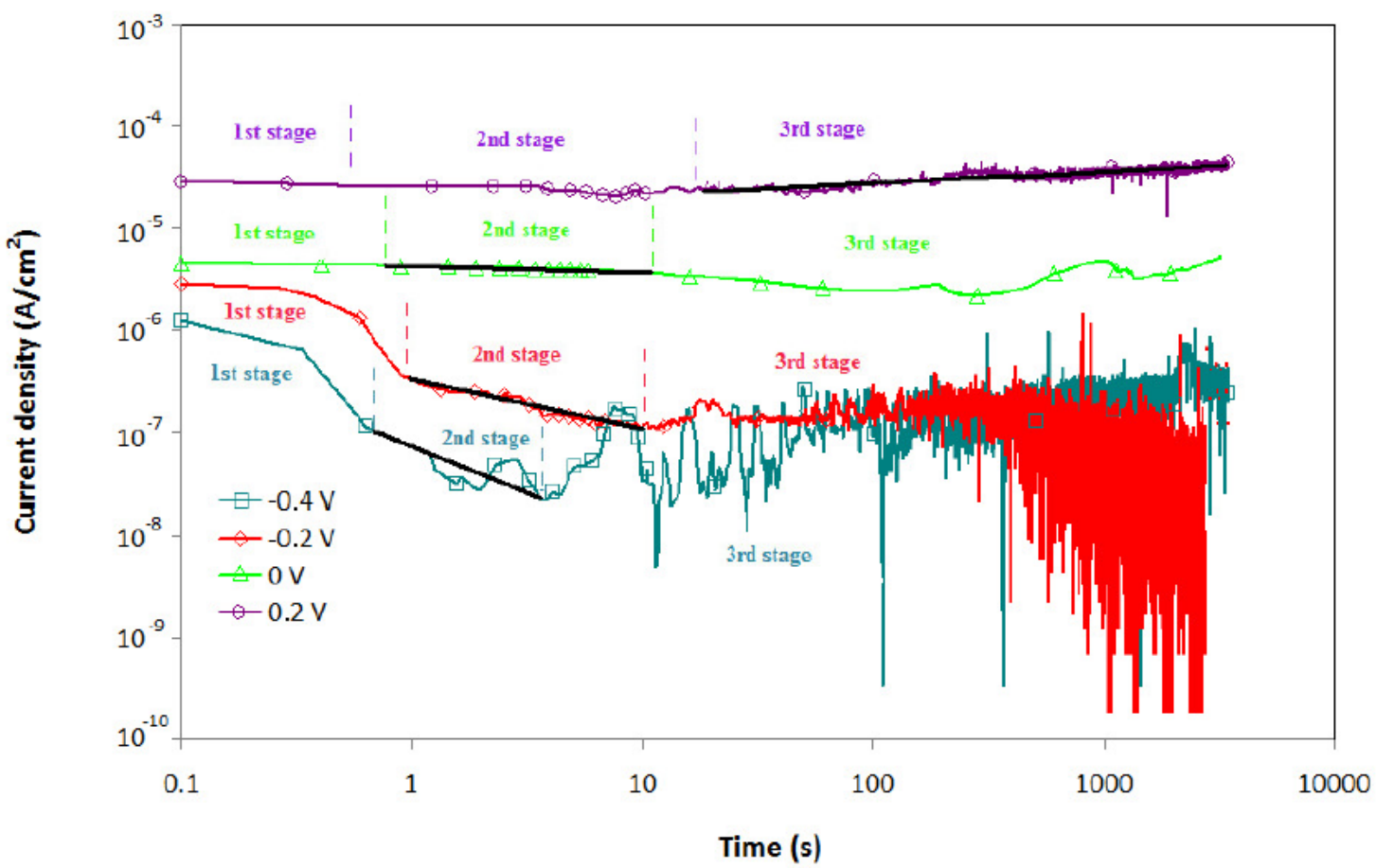

Fig. 9. Plots of $i(t) v s t$ in logarithmic scale obtained just after disconnecting cavitation, for Alloy 31 in $992 \mathrm{~g} / 1 \mathrm{LiBr}$ solution at the four chosen potentials. The linear fits used to obtain the parameters $n$ and $b$ are also shown. 

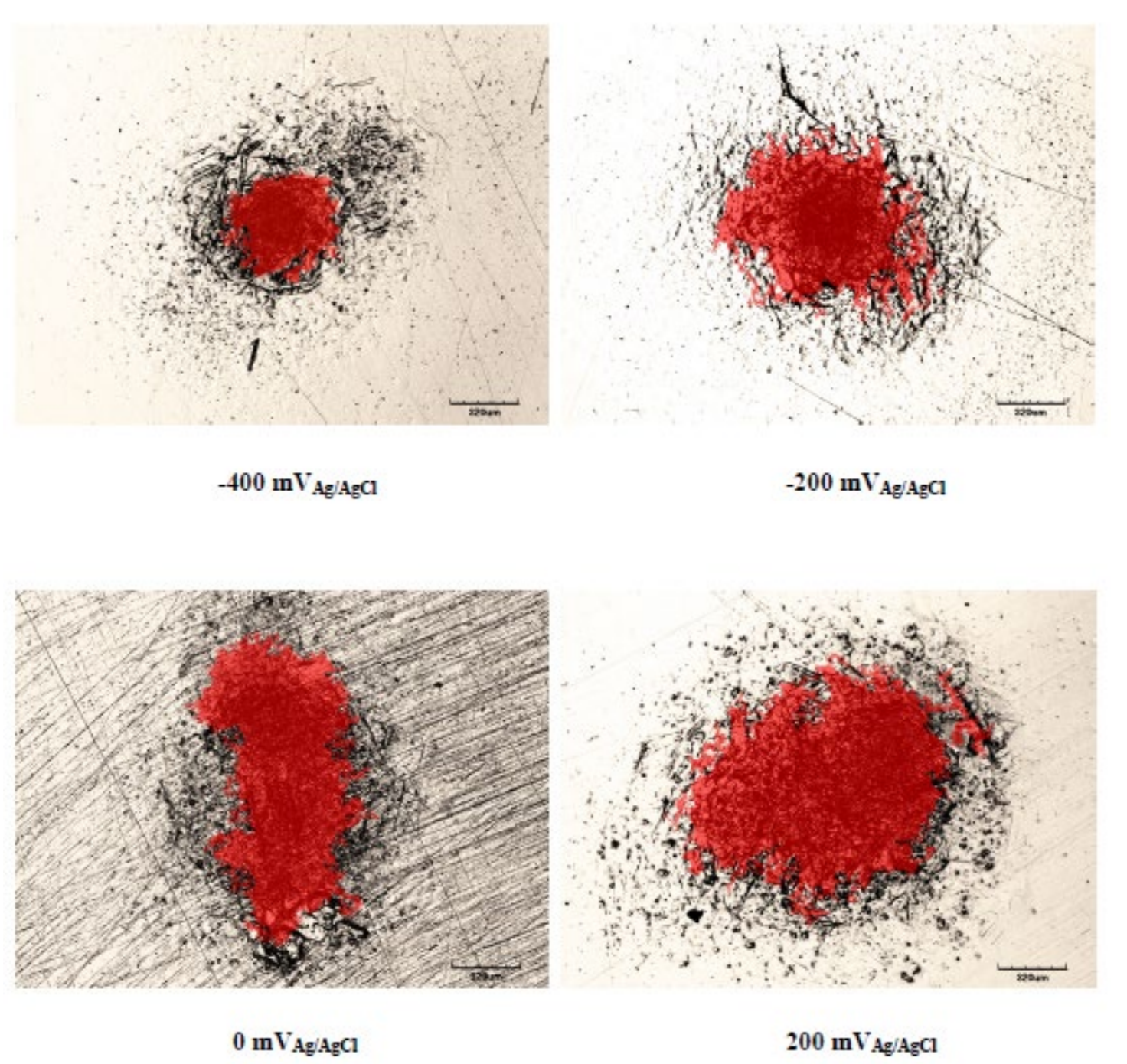

Fig. 10. Micrographs of the damaged surfaces of Alloy 31 in $992 \mathrm{~g} / 1 \mathrm{LiBr}$ solution at the four picked potentials. The micrographs were taken using the Confocal Laser Microscope. The red zones are the areas of maximum damage, obtained from binarized images. 


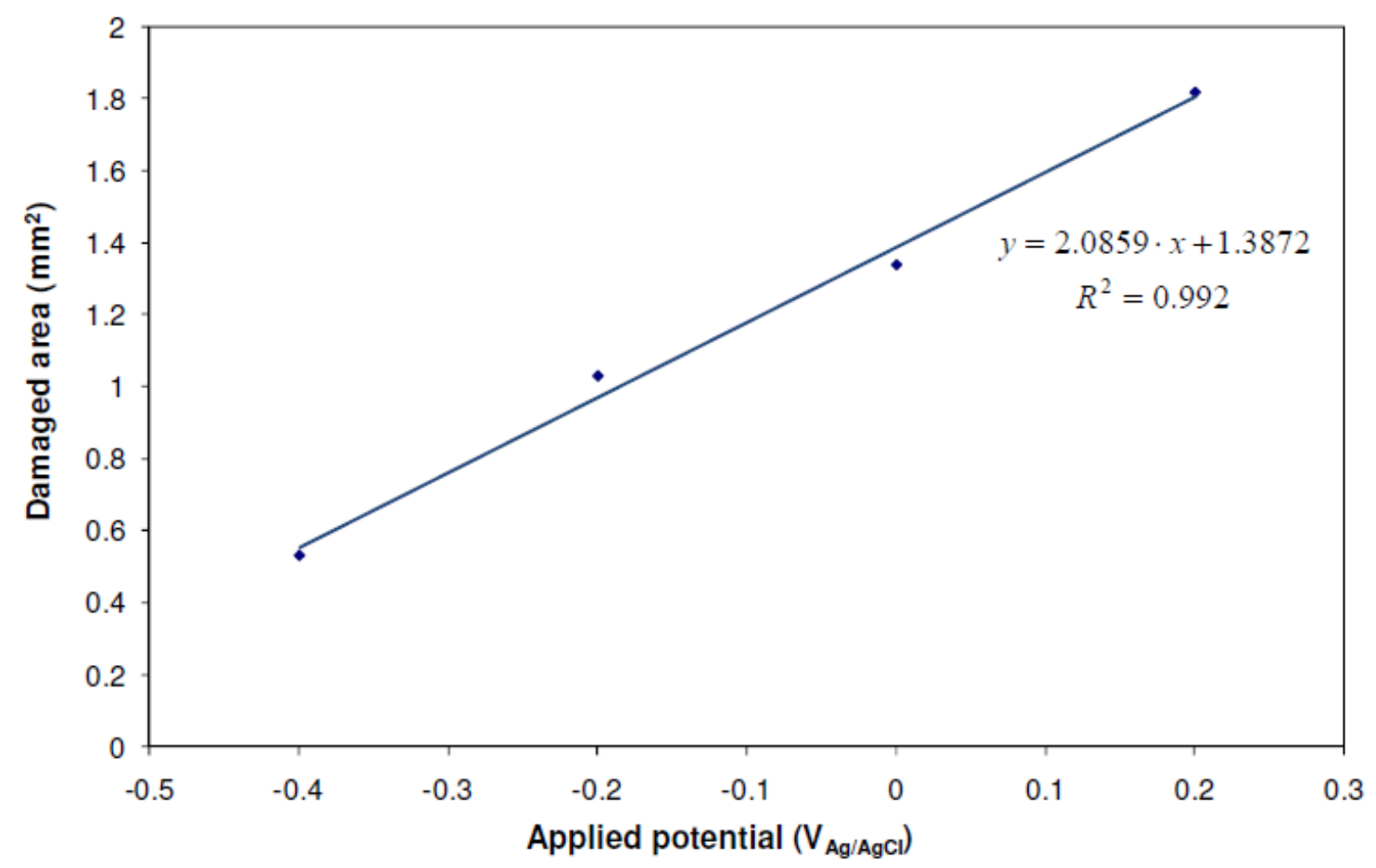

Fig. 11. Damaged area at the different applied potential for Alloy 31 in $992 \mathrm{~g} / 1 \mathrm{LiBr}$ solution.

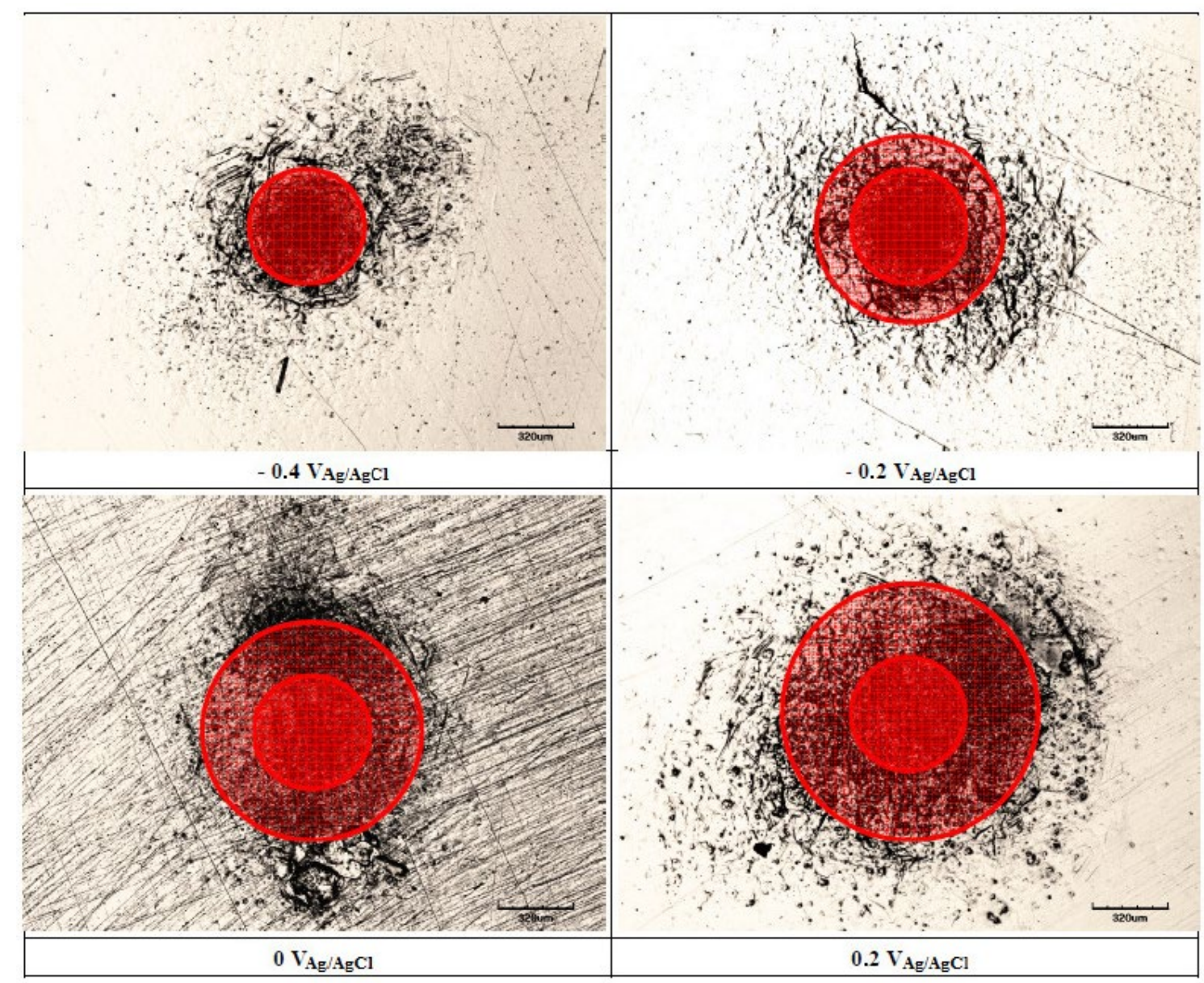


Fig. 12. Areas of maximum depth represented with circular shape in distilled water (inner circles) and in the $992 \mathrm{~g} / \mathrm{l} \mathrm{LiBr}$ solution (outer circles). 